[Special Paper]

\title{
Numerical Investigation of Sunroof Buffeting for Hyundai Simplified Model $\mathrm{HSM}$ 의 썬루프 버페팅 수치해석
}

\author{
Ashok Khondge* and Myunghoon Lee ${ }^{\dagger}$ \\ 컹기 아속.이 명 훈
}

(Received November 19, 2013 ; Revised December 23, 2013 ; Accepted December 23, 2013)

Key Words : HSM(현대간략모델), DES(Detached Eddy Simulation), CFD(전산유체역학), Sunroof Buffeting(썬루프 버페팅), ANSYS Fluent(앤시스 플런트)

\begin{abstract}
Hyundai Motor Group(HMG) carried out experimental investigation of sunroof buffeting phenomena on a simplified car model called Hyundai simplified model(HSM). HMG invited participation from commercial CFD vendors to perform numerical investigation of sunroof buffeting for HSM model with a goal to determine whether CFD can predict sunroof buffeting behavior to sufficient accuracy. ANSYS Korea participated in this investigation and performed numerical simulations of sunroof buffeting for HSM using ANSYS fluent, the general purpose CFD code. First, a flow field validation is performed using closed sunroof HSM model for $60 \mathrm{~km} / \mathrm{h}$ wind speed. The velocity profiles at three locations on the top surface of HSM model are predicted and compared with experimental measurement. Then, numerical simulations for buffeting are performed over range of wind speeds, using advanced scale resolving turbulence model in the form of detached eddy simulation (DES). Buffeting frequency and buffeting level are predicted in simulation and compared with experimental measurement. With reference to comparison between experimental measurements with CFD predictions of buffeting frequency and level, conclusion are drawn about predictive capabilities of CFD for real vehicle development.
\end{abstract}

\section{요 약}

현대자동차그룹은 $\mathrm{HSM}$ 이라고 불리는 간략화된 차량 모델에 대하여 썬루프 버페팅 현상의 실 험적인 조사를 시행하였다. 현대자동차그룹은 어떤 $\mathrm{CFD}$ 솔버가 충분한 정확도를 가지고 썬루프 버페팅 현상을 예측하는지 조사하기 위해 상용 CFD공급업체의 참여를 요청하였다. ANSYS Korea 는 이번 조사에 참여하여 ANSYS fluent를 이용하여 HSM의 썬루프 버페팅에 대한 수치해석을 수행하였다. 먼저 유동장 검증을 위해 풍속 $60 \mathrm{~km} / \mathrm{h}$ 에 대하여 썬루프가 닫힌 $\mathrm{HSM}$ 모델에 대하여 해석을 수행하였다. HSM상부 면의 세 지점에서 속도 분포를 예측하였고, 이는 시험결과와 비교

† Corresponding Author; Member, ANSYS Korea E-mail : myunghoon.lee@ansys.com

Tel : +82-2-3441-5018, Fax :+82-2-3441-5050

* $\quad$ ANSYS India
\# A part of this paper was presented at the KSNVE 2012 Annual Autumn Conference

\$ Recommended by Editor-in-Chief Weuibong Jung

(c) The Korean Society for Noise and Vibration Engineering 


\section{되었다. 그런 다음 고해상도 난류 모델인 $\mathrm{DES}$ 를 이용한 해석이 전 풍속영역에 걸쳐 수행되었} 다. 버페팅 주파수와 버페팅 음압레벨이 예측되었고, 이는 시험결과와 비교되었다. 이를 통해 실 제 차량 개발을 위한 $\mathrm{CFD}$ 의 예측 가능성에 대하여 결론을 얻을 수 있었다.

\section{Nomenclature}

\section{dB : Decibel}

$e \quad$ : Turbulent dissipation $\operatorname{rate}\left(\mathrm{m}^{2} / \mathrm{s}^{3}\right)$

$k \quad:$ Turbulent kinetic energy $\left(\mathrm{m}^{2} / \mathrm{s}^{2}\right)$

$p \quad$ : Static pressure fluctuations

$p_{\text {ref }}:$ Reference pressure

$S P L$ : Sound pressure level

$U_{\infty}$ : Free stream velocity in $x$ direction

$u \quad$ : Local velocity in $x$ direction

\section{Introduction}

Buffeting is a low frequency and high sound pressure level noise generated due to open sunroof or side windows. It is known to cause discomfort to passengers of road vehicles. Over past decade, significant research activities are published to understand the general mechanism of buffeting noise.

With open sunroof, passenger cabin of road vehicle acts as a cavity. Buffeting phenomena can be considered as cavity noise. Cavity noise is generated as unsteady shear layer established at the upstream edge of the cavity. Vortices shed from the upstream edge are convected downstream along the flow. Vortices break down as they impinge to downstream edge of the opening. This generates pressure waves which propagate inside as well as outside the cavity. This process occurs periodically with frequency. If this frequency coincides with natural frequency of cavity a resonance will occur as in Helmholtz resonator. In passenger vehicle this resonance phenomena is buffeting ${ }^{(1)}$. The buffeting frequency depends on the speed of the vehicle and geometry of the opening $^{(2)}$. For passenger vehicles, this frequency is usually very low $(20 \mathrm{~Hz})$. However, buffeting is felt as a pulsating wind force inside passenger cabin which can be very discomforting to occupants. Therefore, it is important to consider a buffeting during vehicle design development from passenger comfort point of view.

In this paper we first discuss briefly the 2nd benchmark of commercial wind noise programs for Hyundai simplified buffeting $\operatorname{model}^{(3)}$, associated geometry model, flow and acoustics measurement. Then we discuss the simulation methodology in terms of mesh consideration, turbulence model, and solution procedure for both flow field validation and buffeting prediction.

\section{Hyundai Simplified Buffeting Model}

Hyundai simplified buffeting model used in experimental investigation is shown in Fig. 1. A sunroof opening $(410 \mathrm{~mm} \times 200 \mathrm{~mm})$ is made from the $305 \mathrm{~mm}$ downstream of top curved edge. The external skin thickness of model is $10 \mathrm{~mm}$. Figure 2
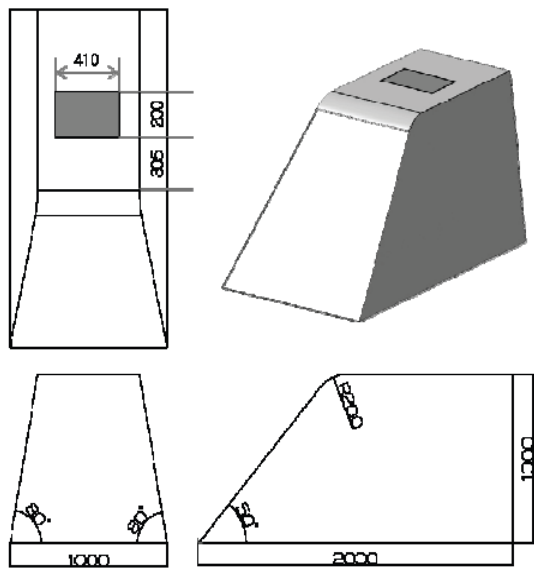

Fig. 1 Specification of Hyundai simplified buffeting model 


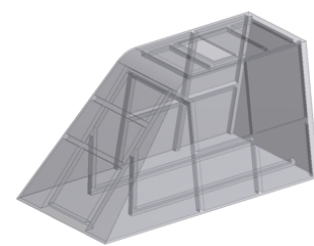

(a)

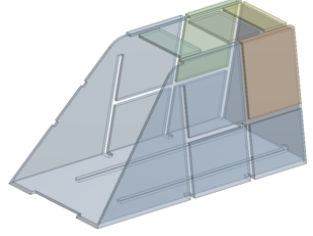

(b)
Fig. 2 The frame structure (a) and the absorbing material (b) geometry
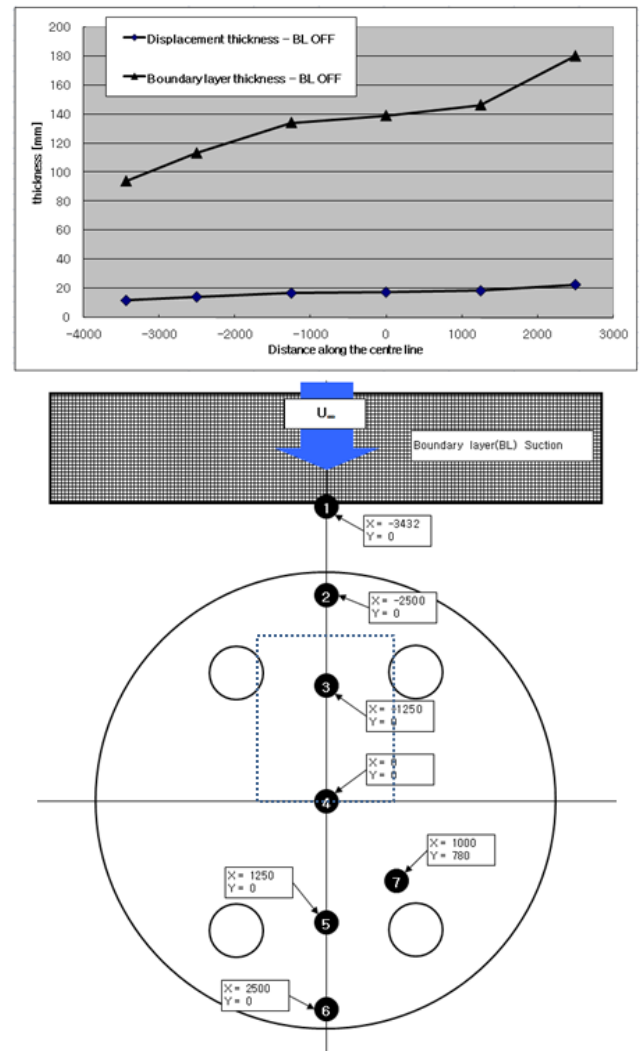

Fig. 3 Boundary layer thickness and displacement thickness and placement of on turntable

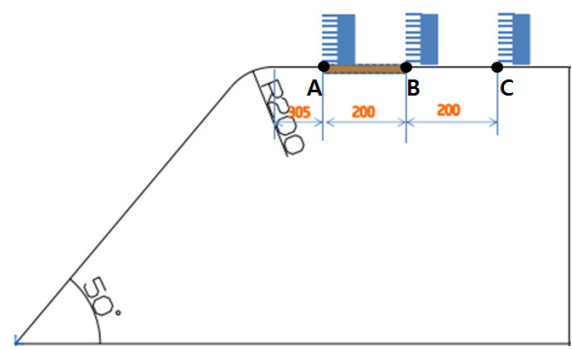

Fig. 4 Measurement positions of the velocity profiles shows the details of internal structures and sound absorbing pads used inside the HSM cabin. The inside air volume of cavity is equal to $1.107 \mathrm{~m}^{3}$. For sunroof buffeting experiments, boundary layer off condition is used at nozzle inlet. Fig. 3 describes boundary layer \& displacement thickness development along the centerline and the position of model on turn table. The velocity profile measurement is carried out with sunroof closed condition. Figure 4 shows the three locations namely A, B and C on the centerline of the model where velocity is measured. Sound pressure level is measured inside the cavity. With the position of model shown in Fig. 3, the sound pressure level measurement probe is located at $(1000,500$, $500) \mathrm{mm}$. For detailed description of experimental setup and measurements refer $^{(3)}$.

The same model is used in CFD simulations with inlet boundary condition derived from experimental measurement of boundary layer profile at inlet location.

\section{Simulation Methodology}

Numerical simulations for flow validation and buffeting predictions are carried out using finite volume based general purpose CFD code ANSYS fluent 14.0. In this section we discuss meshing considerations, turbulence model, boundary conditions, and solution procedure for flow and buffeting analysis.

\subsection{Mesh}

Figure 5 shows the placement of model in the virtual wind tunnel constructed around the turn table. The model placement on turn table is precisely maintained as used in experimental measurements.

In this study hybrid mesh consisting of hex-core, tetrahedral and prism elements is chosen. The surface mesh is generated using preprocessing tool ANSYS Meshing. The volume mesh is generated using 


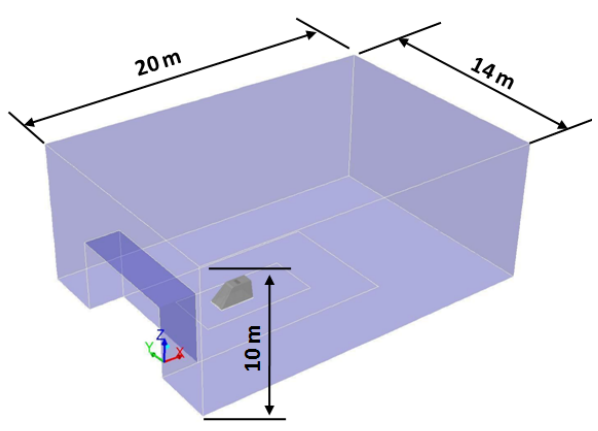

Fig. 5 Computational domain and model placement inside virtual wind tunnel

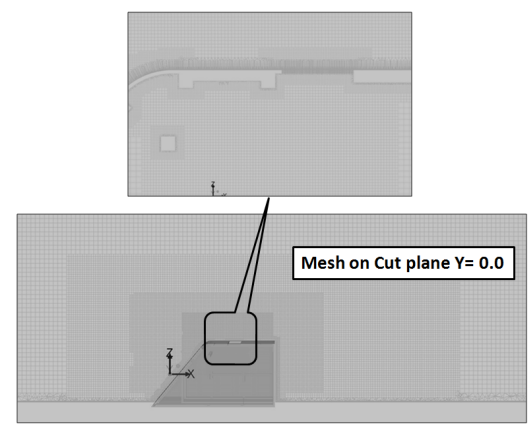

Fig. 6 Volume mesh on centerline cut section

ANSYS TGrid. A layered mesh consisting of 20 prism layers is generated from the tunnel floor and from HSM boundaries with the first cell height of $0.00025 \mathrm{~m}$ and uniform growth ratio of 1.15. Figure 6 shows mesh on centerline cut plane along with a close up view of mesh around sunroof area.

Total mesh count is approximately 22.5 million cells. For accurate prediction of velocity profiles, it is important to generate the prism layers from HSM external boundaries and fine mesh around the HSM geometry. During the mesh generation a surface is created at the sunroof opening with the purpose of dual use of the meshed model. When this surface is made as "wall" boundary in ANSYS fluent one can isolate the cavity and solve the exterior flow filed only. On the hand, when this surface is made as "interior" in ANSYS fluent code, it can be used for buffeting simulations. This is the reason to use the same model of 22.5 million cells for buffeting studies. However buffeting phenomena can be predicted accurately using much smaller meshed model using ANSYS fluent code. This has been demonstrated in past using ANSYS fluent code and published in literature ${ }^{(4,5)}$.

\subsection{Solver, Turbulence Model and BCs}

For flow field validation and prediction of velocity profiles at three locations (A, B \& C) as described in Fig. 4, a steady state simulation is performed for $60 \mathrm{~km} / \mathrm{h}$ wind speed. In this simulation, the surface at sunroof opening is made as "wall" boundary whereby isolating the cavity and simulating only external flow. The inlet boundary condition is derived using boundary layer velocity profile of $u / U_{\infty}$ at point 1 as shown in Fig. 3 and applied as velocity profile at the nozzle inlet boundary using $U_{\infty}=60 \mathrm{~km} / \mathrm{h}$. Table 1 shows the details of solver setup, turbulence model and boundary conditions used in this simulation.

Figure 7 and 8 describes the boundary conditions and boundary layer velocity profile for BL OFF condition 1 respectively

The same meshed model and same boundary conditions are used for buffeting simulations using unsteady solver option. Table 2 shows the details of solver setup, turbulence model and boundary conditions used in the buffeting simulations. A scale resolving detached eddy simulation(DES) turbulence model was chosen. The implementation of DES SA(S-A production vorticity based) model in ANSYS fluent 14.0 is described in detail in reference $^{(6)}$.

The buffeting simulations were run using seven different wind speeds $(20 \mathrm{~km} / \mathrm{h}, 30 \mathrm{~km} / \mathrm{h}, 40 \mathrm{~km} / \mathrm{h}$, $50 \mathrm{~km} / \mathrm{h}, 60 \mathrm{~km} / \mathrm{h}, 80 \mathrm{~km} / \mathrm{h}$ and $100 \mathrm{~km} / \mathrm{h})$. Air is modeled as compressible fluid using ideal gas law. It has been shown in published literature (7) $^{(7)}$ that, to accurately model noise maximization 


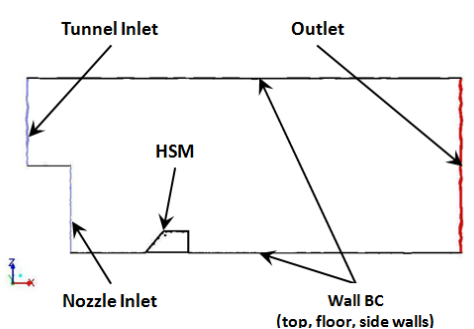

Fig. 7 Boundary conditions

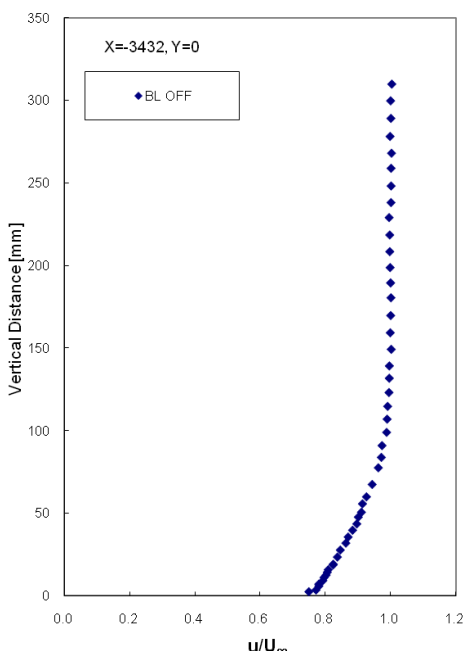

Fig. 8 Boundary layer velocity profile at point 1 nozzle inlet $(x=-3432 \mathrm{~mm}, y=0)$ as per test condition

Table 1 Solver setup, turbulence model \& boundary condition details for flow field validation simulation $(60 \mathrm{~km} / \mathrm{h})$

\begin{tabular}{c|c}
\hline \hline Function & Settings \\
\hline Solver & $\begin{array}{c}\text { Steady state, pressure } \\
\text { based coupled solver, least } \\
\text { square cell based gradient } \\
\text { scheme }\end{array}$ \\
\hline Material & Air as Ideal Gas \\
\hline Turbulence model & $\begin{array}{c}\text { Realizable k- } \varepsilon \text {, enhanced } \\
\text { wall treatment }\end{array}$ \\
\hline Pressure discretization & 2nd Order \\
\hline Momentum discretization & 2nd Order up-wind \\
\hline Turbulence & 2nd Order up-wind \\
\hline Energy discretization & 2nd Order up-wind \\
\hline
\end{tabular}

Boundary conditions :

1. Nozzle inlet - velocity inlet with BL OFF velocity profile $\left(U_{\infty}=60 \mathrm{~km} / \mathrm{h}\right)$

2. Tunnel inlet - pressure inlet(gauge total pressure $=0 \mathrm{~Pa}$ )

3. Tunnel outlet - pressure outlet(gauge pressure $=0 \mathrm{~Pa}$ )

4. Tunnel top, floor, sides - wall boundary(no-slip)
Table 2 Solver setup, turbulence model \& boundary condition details for buffeting simulations

\begin{tabular}{|c|c|}
\hline Function & Settings \\
\hline Solver & $\begin{array}{l}\text { Pressure based solver, } \\
\text { unsteady, least square cell } \\
\text { based gradient scheme }\end{array}$ \\
\hline Material & Air as ideal gas \\
\hline Time formulation & 2nd order implicit \\
\hline Turbulence model & $\begin{array}{l}\text { DES SA(S-A production } \\
\text { vorticity based) }\end{array}$ \\
\hline Pressure velocity coupling & SIMPLEC \\
\hline Pressure discretization & 2nd order \\
\hline Momentum discretization & $\begin{array}{l}\text { Bounded central } \\
\text { differencing }\end{array}$ \\
\hline $\begin{array}{l}\text { Modified turbulent } \\
\text { viscosity }\end{array}$ & 2nd order up-wind \\
\hline Energy discretization & 2 nd order up-wind \\
\hline \multicolumn{2}{|c|}{$\begin{array}{l}\text { Boundary Conditions : } \\
\text { 1. Nozzle inlet }- \text { velocity inlet with BL OFF velocity } \\
\text { profile }\left(U_{\infty}=20 \mathrm{~km} / \mathrm{h}, 30 \mathrm{~km} / \mathrm{h}, 40 \mathrm{~km} / \mathrm{h}, 50 \mathrm{~km} / \mathrm{h} \text {, }\right. \\
60 \mathrm{~km} / \mathrm{h}, 80 \mathrm{~km} / \mathrm{h} \text { and } 100 \mathrm{~km} / \mathrm{h}) \\
\text { 2. Tunnel inlet }- \text { pressure inlet }(\text { gauge total pressure }=0 \mathrm{~Pa}) \\
\text { 3. Tunnel outlet }- \text { pressure outlet(gauge pressure }=0 \mathrm{~Pa}) \\
\text { 4. Tunnel top, floor, sides - wall boundary(no-slip) }\end{array}$} \\
\hline
\end{tabular}

phenomena for a simple cavity using CFD, it is necessary to include the compressibility in the modeling to propagate the pressure waves at the local speed of sound in the flow field. This ensures accurate modeling of interaction between the source mechanisms driven by convection effect, which determines the buffeting frequency, and propagation of the resultant pressure waves inside the cavity volume. The former is an incompressible process while the latter is compressible. Thus the usual assumption that compressibility may be neglected due to low convective Mach Numbers in the passenger compartment is inadequate.

\subsection{Solution Procedure for Simulation}

Each speed case of buffeting simulations is first run in steady state mode for approx 1000 iterations using realizable $\mathrm{k}-\varepsilon$ turbulence model with enhanced wall treatment and pressure based coupled solver. Then the steady state flow field is used to initialize the unsteady flow. A time step 
of 0.00025 seconds is chosen to run unsteady flow. It is much smaller than the time period of the frequency of interest, $\sim 20 \mathrm{~Hz}$. Within each time step the number of sub-iterations is set to 8 and it is observed to be sufficient as residuals for each equation dropped more than 3 orders of magnitude within each time step. The pressure monitor is created at $(1000,500,500) \mathrm{mm}$, microphone location used in experimental measurement. Static pressure is recorded at each time step. After the initial process in about 300 time steps, the pressure signal reaches dynamically stable periodic fluctuations. Subsequently, time history of pressure fluctuation is recorded for the signal processing. Table 3 outlines simulation flow time, signal samples used for acoustics analysis. Fast Fourier transform(FFT) with Hanning window and $50 \%$ signal overlap is applied to transform the recorded time domain signal to the spectral format and it is expressed as sound pressure level(SPL) in $\mathrm{dB}$ units as function of frequency.

$$
S P L(\mathrm{~dB})=10 \times \log _{10}\left(\frac{p}{p_{\text {ref }}}\right)^{2}
$$

Where, $p$ is the amplitude of pressure fluctuation in $\mathrm{Pa}$ and the reference pressure $p_{\text {ref }}=20 \times 10^{-6} \mathrm{~Pa}$.

Table 3 Simulated physical time and signal samples used for FFT in buffeting simulations

\begin{tabular}{c|c|c|c}
\hline \hline $\begin{array}{c}\text { Speed } \\
(\mathrm{km} / \mathrm{h})\end{array}$ & $\begin{array}{c}\text { Simulated } \\
\text { physical time } \\
(\mathrm{sec} .)\end{array}$ & $\begin{array}{c}\text { Signal } \\
\text { duration* } \\
(\mathrm{sec} .)\end{array}$ & $\begin{array}{c}\text { Min. frequency } \\
\text { resolution(Hz) }\end{array}$ \\
\hline 20 & 2.472 & 1.00 & 1.00 \\
\hline 30 & 2.030 & 1.10 & 1.00 \\
\hline 40 & 1.224 & 0.75 & 1.50 \\
\hline 50 & 2.35 & 1.00 & 1.00 \\
\hline 60 & 1.847 & 0.85 & 1.25 \\
\hline 80 & 1.812 & 0.85 & 1.25 \\
\hline 100 & 2.067 & 1.00 & 1.00 \\
\hline
\end{tabular}

FFT window type - hanning

$\%$ signal overlap $-50 \%(*$ Signal duration includes the $50 \%$ signal overlap)

\section{Simulation Results and Discussion}

\subsection{Flow Field Predictions}

In the experimental testing, velocity profiles are measured at locations $\mathrm{A}, \mathrm{B}$ and $\mathrm{C}$ as shown in Fig. 4. In this experiment, $60 \mathrm{~km} / \mathrm{h}$ speed was chosen with sunroof closed condition and it is reported in [2]. The velocity profiles are computed at the same locations in steady state numerical simulation and compared with experimental measurement. Figs. 9, 10 and 11 show this comparison at location A,

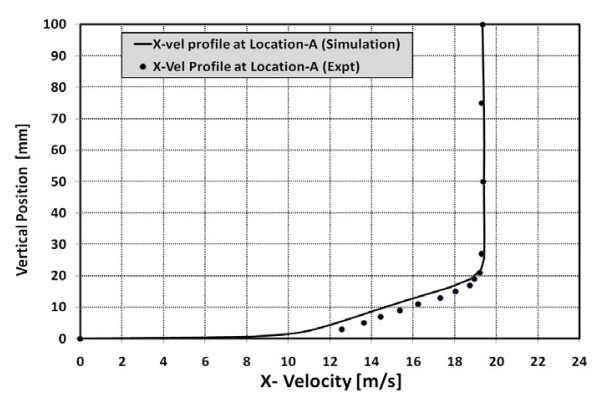

Fig. 9 X-velocity profile comparison at location A

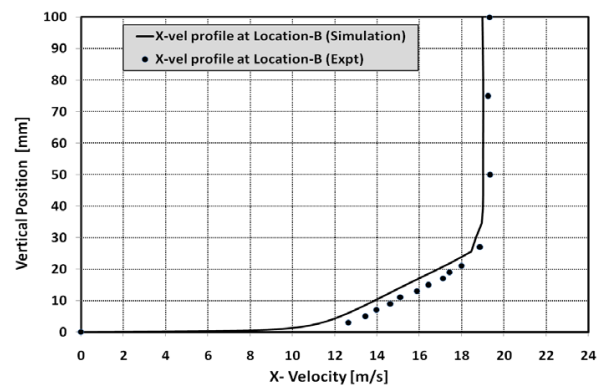

Fig. $10 \mathrm{X}$-velocity profile comparison at location B

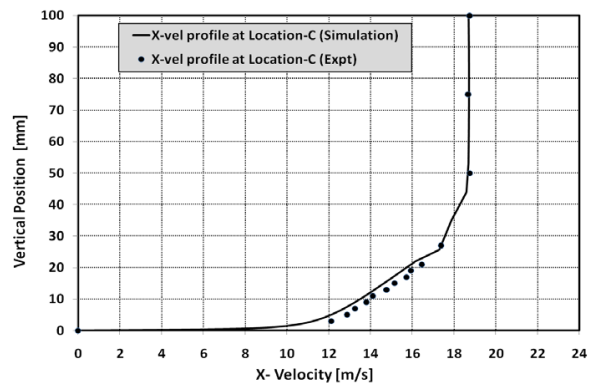

Fig. $11 \mathrm{X}$-velocity profile comparison at location $\mathrm{C}$ 
$\mathrm{B}$ and $\mathrm{C}$ respectively. The steady state flow field in terms of velocity and pressure contours is shown in Fig. 12 and 13. The velocity profiles at locations $\mathrm{A}, \mathrm{B}$ and $\mathrm{C}$ computed in simulation compares well with experimental measurement. The comparison is good in both the viscous boundary layer region as well as core region. This ensures that the meshed used in computational model is adequate to capture the flow filed details and hence the same model is used for buffeting simulations.

\subsection{Aeroacoustics Predictions}

Figure 14 shows the buffeting spectra at microphone location $(1000,500,500) \mathrm{mm}$ inside the

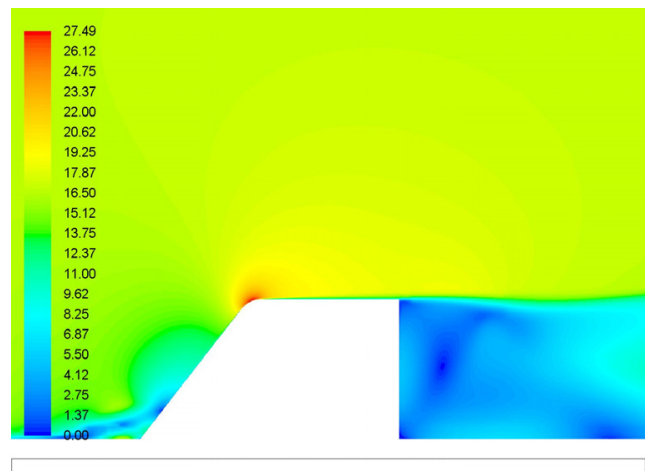

Contours of Velocity Magnitude ( $\mathrm{m} / \mathrm{s})$

Fig. 12 Steady sate velocity field at $y=0$ cut plane

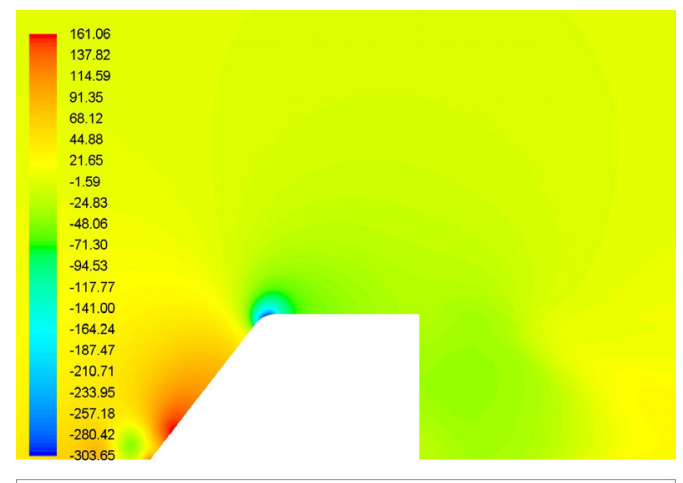

Contours of Static Pressure (pascal)

Fig. 13 Steady sate static pressure field at $y=0$ cut plane
HSM cabin computed in numerical simulations using ANSYS fluent code for seven speeds. Computations for speed of $70 \mathrm{~km} / \mathrm{h}$ and $90 \mathrm{~km} / \mathrm{h}$ are not carried out. The simulation results suggest that buffeting onsets at $40 \mathrm{~km} / \mathrm{h}$ and the peak buffeting is observed at speed somewhere between 50 and $60 \mathrm{~km} / \mathrm{h}$. Acoustics spectra for 50 and $60 \mathrm{~km} / \mathrm{h}$ shows 2 nd and 3rd peaks representing harmonics of resonance frequency. This can be seen in Fig. 15, where spectra for $50 \mathrm{~km} / \mathrm{h}$ and $60 \mathrm{~km} / \mathrm{h}$ are plotted again for the sake of clarity.

The other important sets of results are illustrated in Fig. 16 and 17, which plots the buffeting resonance frequency and peak sound pressure level in comparison to experiments over entire speed sweeps respectively. The comparison shown in Fig. 16 suggests that numerical simulation captures

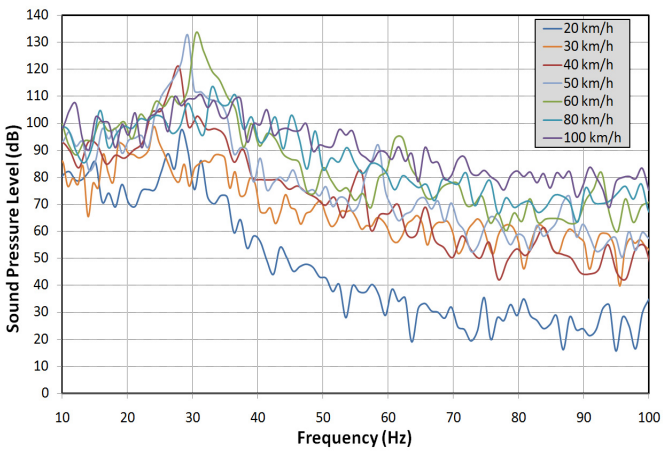

Fig. 14 Frequency spectra for seven speed cases(20, $30,40,50,60,80$ and $100 \mathrm{~km} / \mathrm{h}$ )

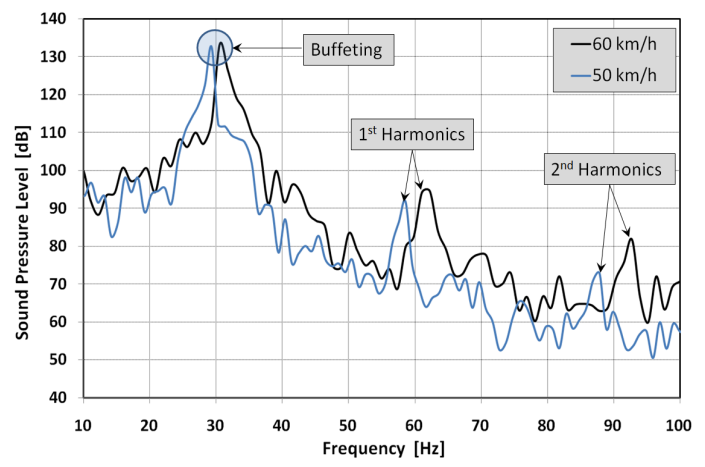

Fig. 15 Frequency spectra 50 and $60 \mathrm{~km} / \mathrm{h}$ speed (1st and 2 nd harmonics of buffeting) 
overall trend very well with little offset of approximately 2 or $3 \mathrm{~Hz}$ in predicting buffeting frequency over entire speed sweep when compared with experiments. This offset may be attributed to small time domain signal size that is used for FFT analysis.

Buffeting levels computed in numerical simulations show some discrepancy when compared with experiments. Experimental measurement shows maximum buffeting level at $50 \mathrm{~km} / \mathrm{h}$ speed, however, numerical simulations predict maximum buffeting level at speed somewhere between $50 \mathrm{~km} / \mathrm{h}$ and $60 \mathrm{~km} / \mathrm{h}$. The buffeting level compares well at low speeds, 30 to $40 \mathrm{~km} / \mathrm{h}$ and at high speeds $80 \sim 100 \mathrm{~km} / \mathrm{h}$. However, for speeds of 50 to $70 \mathrm{~km} / \mathrm{h}$ numerical simulations over predict buffeting level by 4 to $10 \mathrm{~dB}$ as compared with experiments. In the numerical simulations all interior surfaces(pads) used in HSM cabin are assumed to be

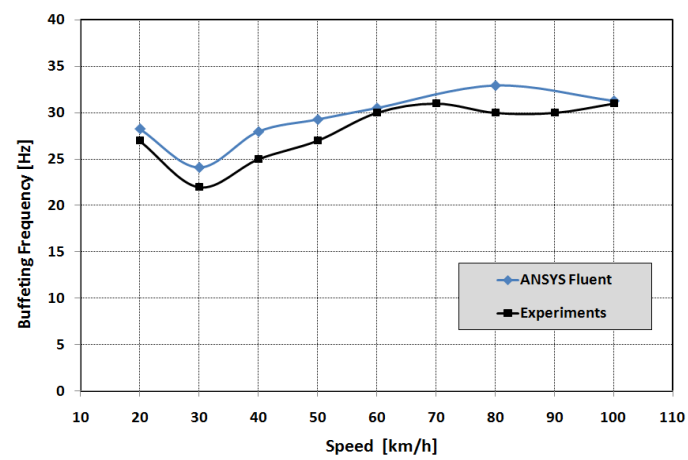

Fig. 16 Buffeting frequency vs speed

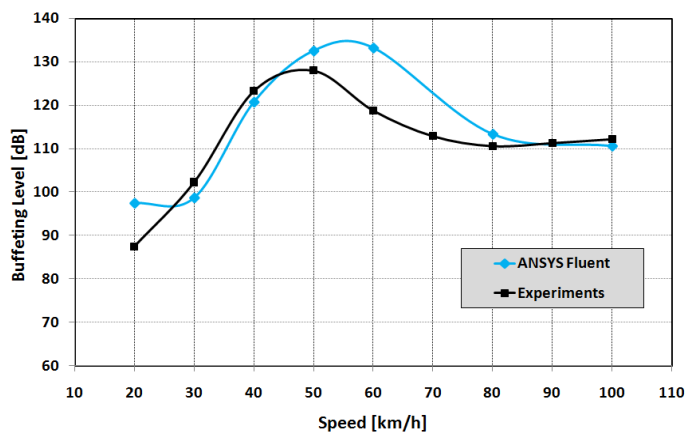

Fig. 17 Buffeting level vs speed acoustically rigid walls. Acoustically rigid surfaces tend to reflect pressure wave more strongly than sound absorbing surfaces and hence numerical simulations over predict the buffeting levels.

During the buffeting simulation, data sampling for time statistics option was used. Using this option ANSYS fluent will compute the time average (mean) of the instantaneous values and root-mean-squares of the sampled variables or

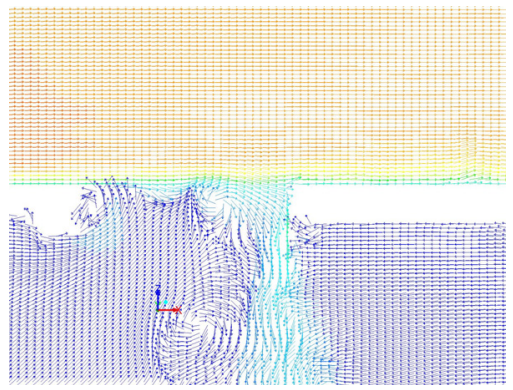

Fig. 18 Time averaged velocity vectors near sunroof opening area $-20 \mathrm{~km} / \mathrm{h}$

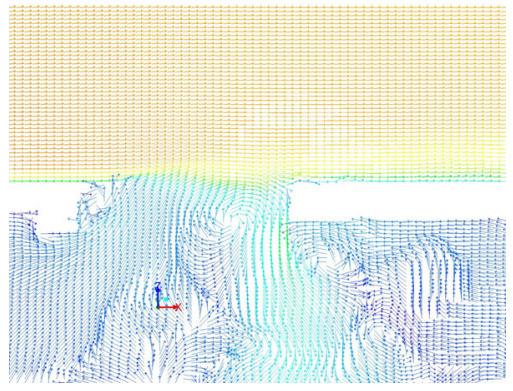

Fig. 19 Time averaged velocity vectors near sunroof opening area $-60 \mathrm{~km} / \mathrm{h}$

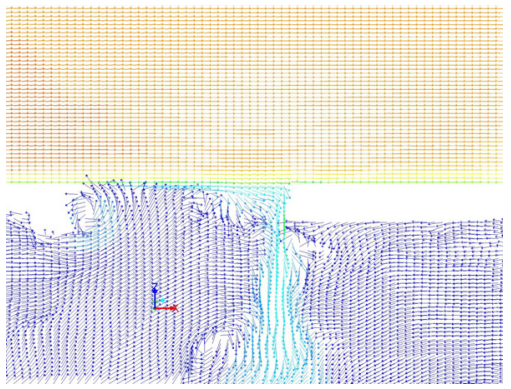

Fig. 20 Time averaged velocity vectors near sunroof opening area $-100 \mathrm{~km} / \mathrm{h}$ 
quantities like pressure, velocity or forces. Using the data sampling for time statistics, time averaged velocity vectors are plotted near the sunroof opening area for $20 \mathrm{~km} / \mathrm{h}, 60 \mathrm{~km} / \mathrm{h}$ and $100 \mathrm{~km} / \mathrm{h}$ speeds. These plots are shown in Figs. 18, 19 and 20 respectively. A strong vortex at trailing edge of sunroof opening is observed in case of $60 \mathrm{~km} / \mathrm{h}$ speed, such vortex is weak for $20 \mathrm{~km} / \mathrm{h}$. For 100 $\mathrm{km} / \mathrm{h}$ speed, most of the flow rushes over the cavity with weak stream coming inside the cavity at trailing edge of the sunroof. These flow details shed some light on reasons for strong buffeting levels for speed in the range of 50 to $70 \mathrm{~km} / \mathrm{h}$, buffeting offsets for speed higher than $70 \mathrm{~km} / \mathrm{h}$.

\section{Future Work}

In the present numerical study the real world effects(RWE) - sound absorption by interior surfaces, leakage and wall compliance are not considered. Authors are continuing this numerical study further to account real world effects in CFD modeling. Other aspects like performing buffeting simulations with smaller mesh count models to check grid dependency, numerical acoustics resonance tests(ART) to compute quality factors will be part of the further study.

\section{Acknowledgements}

The authors would like to thank Dr. Ih, Kang duck, Cho Munhwan, Kim Hyoug-gun and Oh Chisung of HKMC NVH 1 Reserach Lab for providing the experimental data and thank Sean Kim of ANSYS Korea for supporting for this work.

\section{References}

(1) Kook, H. And Mongeau, L., 2002, Analysis of the Periodic Pressure Fluctuations Induced by Flow Over a Cavity, Journal of Sound and Vibration, Vol. 251, No.

5, pp. 823 846.

(2) Huco, W. H., 1998, Aerodynamics of Road Vehicles, 4th edition, Society of Automotive Engineers, Inc., Warredale, Pa.

(3) Kim, Y. N., Park, Y. Y., Park, I., Lee, M., Cyr Stephane, Jeon, W. H., Mendoca F., Cho, M., Kim, H. G. and Oh C. S., 2012, The 2nd Benchmark of Commercial Wind Noise Programs for Hyundai Simplified Buffeting Models, Proceedings of the KSNVE Annual Spring Conference, pp. 815 817.

(4) An, C. F., Alaie, S.M., Sovani, S. D., Scislowicz, M. S. and Sing, K., 2004, Side Window Buffeting Characteristics of an SUV, 2004-01,0230, SAE World Congress.

(5) Hendriana, D., Sovani, S. D. and Schiemann, M. K., 2003, On Simulating Passenger Car Side Window Buffeting, 2003-01-1316, SAE world Congress.

(6) ANSYS Software R14.0 Help Manual, 2012.

(7) Inagak, M., Murata, O., Kondoh, T. and Abe, K., 2002, Numerical Prediction of Fluid-resonant Oscillation at Low Mach Number, AIAA Journal, Vol. 40, No. 9, pp. $1823 \sim 1908$.

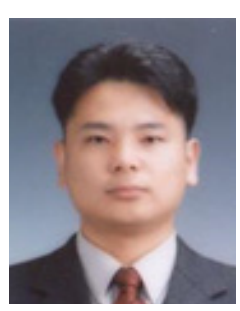

MyungHoon Lee received B.S dgree from Kangwon National University in 2001, and M.S. degree from Hanyang University in 2004. He is currently Fluent/CFX application engineer of ANSYS Korea. His researach interests is aerodynamics and aeacoustics simulation.

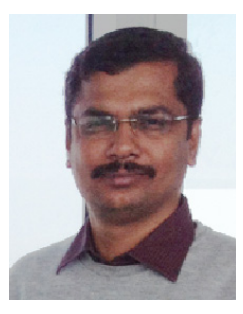

Ashok Khondge received B. Eng degree from University of Mumbai in 1999 and M.Tech degree from Indian Institute of Bombay in 2003. He is currently working as Lead Technology Specialist in ANSYS India. His research interests include vehicle aerodynamics, aeroacoustics and vehicle thermal underhood modeling. 